\title{
Antakya Gazipaşa Caddesi Örneğinin Kentsel Tarihi Peyzaj Açısından Değerlendirilmesi
}

\author{
İdil DAL ${ }^{1 *}$, Iş11 KAYMAZ ${ }^{2}$ \\ ${ }^{1}$ Bartın Üniversitesi, Mühendislik, Mimarlık ve Tasarım Fakültesi, Peyzaj Mimarlı̆̆ı Bölümü,74100, BARTIN \\ ${ }^{2}$ Ankara Üniversitesi, Ziraat Fakültesi Peyzaj Mimarlığı Bölümü, Dışkapı, ANKARA
}

Öz

Antakya tarımsal potansiyeli, ticaret yolları üzerinde bulunması ve zengin su kaynaklarına sahip olması ile birlikte birçok medeniyete ev sahipliği yapmış bir kent konumundadır. Birçok kültüre ev sahipliği yapması kente kimlik katan alanlar oluşmasını sağlamıştır. Ancak kentte yaşanan kentsel büyümeye bağlı hızlı değişim, tarihi dokuyu zedelemekte, ona farklı işlevler yükleyerek kimliğinin giderek bozulmasına neden olmaktadır. Bu çalışmada tarihi kimliği bulunan alanlar Antakya, Gazipaşa Caddesi örneği üzerinden ele alınmıştır. Tarihi dokuda süreç içerisinde meydana gelen değişimlerin boyutlarının ortaya konulması hedeflenmiștir. Alanın mevcut durumunu ortaya koymak ve öneriler geliştirmek adına fotoğraflar çekilmiş, sorun analizi, GZFT analizi, kent imgesi analizi yapılmış ve anket uygulanmıştır. Bu doğrultuda kent kimliğini tehdit eden ve kent kimliğine katkıda bulunan unsurlar belirlenmiştir. Elde edilen bulgularla birlikte kimliğin korunup geleceğe aktarılmasına ilişkin olarak tarihi doku ile uyumlu donatılara, yapılara ve yapısal düzenlemelere ilişkin öneriler geliştirilmiştir. Öneriler sonucunda korumanın çok paydaşlı ve çok disiplinli bir sürece ihtiyacı olduğu belirlenmiştir.

Anahtar Kelimeler: Kentsel tarihi peyzaj, kent kimliği, peyzaj tasarımı, peyzaj yönetimi, Antakya.

\section{Evaluation of Antakya Gazipaşa Street in terms of Urban Historical Landscape}

\begin{abstract}
Antakya is a city that has hosted many civilizations with its agricultural potential, being on trade routes, and having rich water resources. Hosting many cultures, has created areas that add identity to the city. However, the rapid change due to urban growth in the city damages the historical texture and causes its identity to deteriorate gradually by assigning different functions to it. In this study, the areas with historical identity are handled over the example of Antakya, Gazipaşa Street. It is aimed to reveal the dimensions of the changes that have occurred in the historical texture in the process. In order to reveal the current situation of the area and to develop suggestions, photographs were taken, problem analysis, SWOT analysis, city image analysis were made and a questionnaire was applied. In this direction, elements that threaten and contribute to urban identity have been identified. Within the scope of the findings, suggestions have been developed regarding the equipment, structures, and structural arrangements compatible with the historical texture in order to preserve the identity and transfer it to the future. As a result of the recommendations, it has been determined that conservation needs a multi-stakeholder and multi-disciplinary process.
\end{abstract}

Keywords: Urban historic landscape, urban identity, landscape design, landscape management, Antakya. 


\section{Giriş}

Kentler çok işlevli; sürekli gelişen ve ev sahipliği yaptığı toplumun eğitim, rekreasyon, etkileşim ihtiyaçlarının karşılandığı, nüfusu kırsala nazaran oldukça fazla olan ve komşuluk ilişkileri barındıran sosyal bir sistemdir (Keleş, 1980). Literatürde kentler, birbirinden ayırt edildikleri özellikler doğrultusunda çeşitli şekillerde tanımlanmaktadır. Geliştikleri döneme bağlı olarak "Bronz Çağı kenti, Orta Çağ kenti ya da Roma kenti" gibi döneme; "Osmanlı kenti", "Yunan kenti", “Türk kenti”, “Arap kenti” gibi medeniyete, "İslam kenti” gibi dine ya da "Akdeniz kenti” gibi coğrafyaya yönelik olarak tanımlamalara rastlanmaktadır (Ünlü, 2017). Bu tanımlamalar özünde bir kimliğe de işaret etmektedir. Lynch (1960), kimliğin bir nesnenin tanımlanırken diğer nesnelerle eşdeğer olmadığından bahsederek; farklı bir varlık olarak kabul edilmesi gerektiğini belirtip nesnenin tek ve biricik olduğunu savunmakta ve kentleri birbirinden ayıran bu tanımların kentin kimliğini oluşturduğunu belirtmektedir. Öte yandan bir mekânda süregelen ve korunan kimliğin, "yer"e bağlanma ve aidiyet duygusunun gelişmesinde önemli rolü vardır (Kaymaz, 2013). Relph (1976) ise fiziksel bir mekâna ait olma durumunun insanın bir gereksinimi olduğunu ve bu gereksinimin göz ardı edilmesi durumunda gelecekte "yer"in insan için önemli olmayacağını belirtmektedir. Burada kullanılan "yer” kavramı, her ne kadar sözcük olarak Türkçede sıkça “mekân” kelimesi ile eş anlamlı olarak kullanılıyor olsa da Cresswell (2004)'ün ifade ettiği üzere birey tarafından anlam yüklenen ve duygusal olarak bağ kurulan bir mekânı ifade etmektedir. Dolayısıyla bir kentin kimliğinden bahsederken fiziksel bir biçim ya da desenin ötesinde, deneyim ve anlamı da içeren psikolojik ve sosyal süreçler de konuya dâhil olmaktadır.

Peyzaj kavramı içinde ele alındığında ise kentler; insan ve doğal çevrenin karşılıklı etkileşimi ile ortaya çıkan kültürel peyzaj bağlamında değerlendirilmektedir. Birleşmiş Milletler Eğitim, Bilim ve Kültür Örgütü (UNESCO) Dünya Mirası Komitesi'ne göre kültürel peyzaj olarak nitelendirilen alanlar; doğa ve insan ortaklığıyla oluşmuş ürünleri olan, insanların yaşam mekânlarının, doğal çevreden kaynaklanan fiziksel sınırlamaların veya olanakların, tarihsel süreçte birbirini izlemesi ve sosyal, ekonomik ve kültürel güçlerin etkisiyle, zaman içinde geçirdiği evrimin göstergeleri olan alanlardır (UNESCO, 1992). Bir mekâna dair tanımlanan "miras" olgusu, her ne kadar geleneksel bir anlayış olarak çoğunlukla geçmişten günümüze gelen mimari yapılar ya da doku olarak ele alınıyor olsa da aslında iç içe geçmiş çoklu tabakalar olarak hem somut yapılı çevreyi hem de toplulukların soyut kültürel değerlerini kapsamaktadır (Garagnani vd., 2016). Nitekim Kurtar ve Somuncu (2013)'ün de belirttiği üzere kültürü oluşturan eylemler insan ile ilişkilidir ve miras aslında bir kültüre ait olandır.

Kültürel peyzaj kapsamında ele alınan kentsel tarihi peyzajlar ise yukarıda bahsedilen kimlik, yer ve miras kavramları açısından özel bir yere sahiptir. İnsanlığın ortak kültürel mirasının en çeşitli tezahürlerini ortaya koyan, nesiller boyunca şekillenmiş bu alanlar; insanlığın tarih boyunca çabalarının ve isteklerinin önemli kanıtları olarak tüm insanlık için sosyal, kültürel ve ekonomik değerlerdir (UNESCO, 2011). Ahunbay (1996)'ya göre tarihi çevreler, öğretici ve ilgi duyulacak niteliklere sahip olan insan ölçeğine göre düzenlenmiş olup; sosyal açıdan ilişkileri olumlayan ve bireyler arasındaki birlik beraberlik duygusunun artmasını sağlayan mekânları içerirler. Tarihi çevreler, geçmişte nasıl bir mekânda yaşandığını gösteren açık hava müzeleridir (Hatami, 2013). Kent içerisinde tarihi niteliği bulunan kültürel peyzaj alanları, çeşitli aktivitelere ev sahipliği yapan ve kentlilerin birbirleriyle iletişimine olanak veren birer kamusal alan niteliği taşımaktadır. 28 Kasım 2011 tarihli “Tarihi Kentlerin ve Kentsel Alanların Korunması ve Yönetimi” ile ilgili Valetta İlkeleri'nde bu alanlardan, yalnızca dolaşıma ayrılan yerler değil aynı zamanda düşünme, öğrenme ve kentten zevk alma mekânları olarak bahsedilmiştir (ICOMOS 2011).

Nüfusun arttığı kentler başta olmak üzere günümüzde tüm yerleşmelerdeki temel sorunlardan biri, kentin sosyal, kültürel ve mekânsal yapısıyla yeni dönem gelişmelerinin çatışmasından doğan uyumsuzluklardır. Oysa yaşayan ve gelişen bir sistem olarak kentler için değişim kaçınılmazdır. Ancak bu değişimin kentsel tarihi dokunun özgünlük ve bütünlüğünü koruyacak biçimde yönetilmesine olanak tanıyan araçlara ihtiyaç vardır. Valetta İlkeleri kapsamında mekânsal müdahalelerin alanın geleneksel biçimlenmesine saygılı, yerin ruhu ile barışık, mekânın bütünlüğünün ve sürekliliğinin kesintiye uğratmayacak biçimde olmasına vurgu yapılmıştır (ICOMOS, 2011). Özellikle yapılaşma kaynaklı olarak kentsel miras alanları üzerinde tahrip edilme baskısı bulunmaktadır. Bununla birlikte kent merkezinde yer alan tarihi alanların sosyal çöküntü alanlarına dönüşmesi, hatalı müdahale ve yenileme çalışmaları, koruma planlarının olmayışı ya da yetersiz olması, farklı işlevlerle alanın kullanılması (Arabacıoğlu ve Aydemir, 2007; Yurdugüzel ve Özçetin, 2015) gibi nedenler de miras ögeleri ve özellikleri üzerinde olumsuz etkiye neden olmaktadır. Bunun sonucunda somut ve somut olmayan mirası korumaya çalışırken, sürdürülebilir kalkınmanın ve kentsel yaşam kalitesinin bir arada yürütülmesi zorlu bir süreç olarak ortaya çıkmaktadır.

Hatay’ın merkez ilçesi Antakya kurulduğu günden bu yana birçok konuda farklı değerler taşıyan devletlerin 
himayesine girmiştir. Antakya sahip olduğu tarımsal potansiyel, ticaret yolları üzerinde bulunması ve zengin su kaynakları sebebiyle Anadolu ve kuzey Mezopotamya'da göçebe ve yerleşik kavimlerin dikkatini çeken bir bölge olmuştur. Anadolu'daki insan yerleşimleri bakımından en eski kentlerden biridir (Tekin, 2000). Bu farklı devirlerdeki kültürel zenginlikler birikerek kente kimlik katan alanlar oluşturmuştur. Ancak M.Ö. 300 yılında kurulmuş (Demir 1996) olan kentte yaşanan kentsel büyümeye bağlı hızlı değişism, tarihi dokuyu zedelemekte, ona farklı işlevler yükleyerek kimliğinin giderek bozulmasına neden olmaktadır. Bu çalışmada daha önce, özellikle mimarlık alanında pek çok çalışmaya konu olan Antakya'nın, tarihi nitelikteki açık alanların peyzaj bağlamının irdelenmesi hedeflenmiştir. Bu doğrultuda Antakya I. Derece Kentsel Sit Alanı ve III. Derece Arkeolojik Sit Alanı içerisinde bulunan Gazipaşa Caddesi, kendine özgü tarihi dokusu ve farklı özelliklerde (tarihi, dini, sosyal) kullanımlarla çevrelenmiş olması nedeniyle çalışma alanı olarak belirlenmiştir. Çalışmanın amacı durum tespiti üzerinden tarihi kimlik değerinin korunmasına ve güçlendirilmesine yardımcı olacak peyzaj tasarım ve yönetim önerilerinin geliştirilmesidir.

\section{Materyal ve Metot}

\subsection{Materyal}

Çalışmanın birincil materyalini, Antakya’nın Zenginler Mahallesi sınırları içerisinde kalan Gazipaşa Caddesi (Şekil 1) ve yakın çevresine ilişkin yazılı ve mekânsal veriler oluşturmaktadır. Bu amaçla 1/5.000 ölçekli imar planı, koruma amaçlı imar plan notları, konu ile ilgili tez, makale, Antakya ile bilgiler içeren yerli ve yabancı kitaplardan elde edilen dokümanlar ve fotoğrafların yanı sıra alanda gerçekleştirilen gözlem ve anket verilerinden faydalanılmıştır.

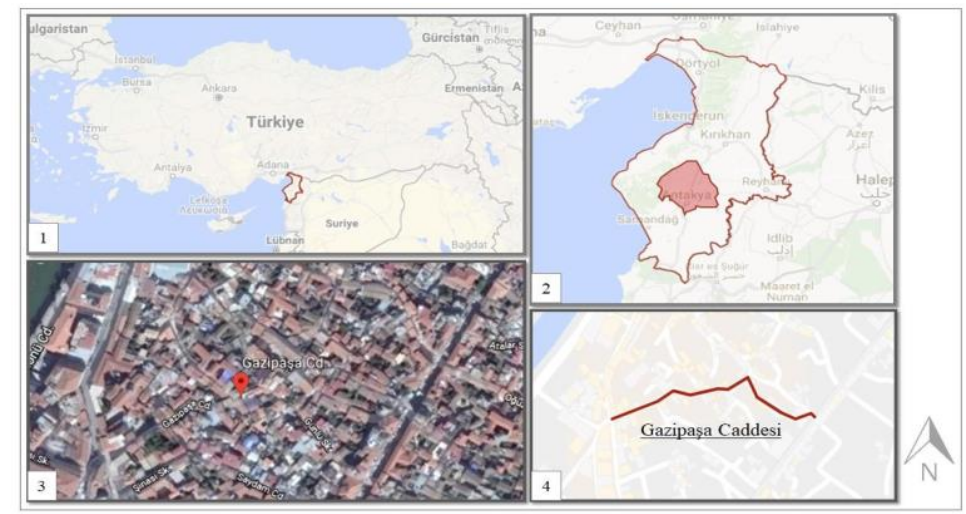

Şekil 1. Gazipaşa Caddesi'nin konumu (Google Earth, 2018).

\subsection{Metot}

Tarihi kent dokusunun araştırılması ve incelenmesini içeren çalışmada temel olarak literatür taraması ve veri toplama, mekâna ilişkin analizler ve değerlendirme yöntemi izlenmiştir. Çalışma alanının durum tespitine ilişkin olarak öncelikle alandaki gözlemlere ve literatür verisine dayanarak sorun analizi gerçekleştirilmiş; ardından Lynch'in Kent İmgesi (1960) çalışması temel alınarak kent imgesi analizi yapılmıştır. Çalışma alanını daha iyi tanımak ve alanı kullanan bireylerin görüşlerini almak amacıyla anket çalışması gerçekleştirilmiştir. Ankete ilişkin sonuç verileri, belirli bir ana kütleyi temsil etme durumu yerine, çalışmayı yönlendirici fikirler üretmede yön gösterici olarak ele alınmış ve bu doğrultuda sentezi gerçekleştirilmiştir. Anket çoktan seçmeli 15 sorudan oluşmaktadır ve 2018 yılı içinde çalışma alanında 50 gönüllü ile yüz yüze gerçekleştirilmiştir. Anket verileri IBM SPSS Statistics 20 yazılımı kullanılarak analiz edilmiştir. Anket sonuçlarının değerlendirilmesi, verilerin sayısal olarak oransal dağılımını belirten frekans analizi üzerinden yapılmıştır. Elde edilen verilerin sentezlenmesiyle kentin kimliğine önemli katkıları bulunan Gazipaşa Caddesi, temel sorun çerçevesinde kentin kimliği ve kültürel değerlerine dayanarak GZFT (SWOT) analiziyle değerlendirilmiştir. Çalışmanın son bölümünde literatür bilgisi, mekânsal analizler ve anketlerle elde edilen bulgular değerlendirilerek tarihi kültürel peyzajın korunması ve gelecek kuşaklara aktarılması adına öneriler geliştirilmiştir. 


\section{Bulgular ve Tartışma}

\subsection{Sorun Analizi}

Gazipaşa Caddesini de içine alan Antakya için ilk imar planı 1948'de hazırlanmış, ancak bu plan uygulamaya konulmayarak 1957 yılında yeni bir imar planı hazırlama yoluna gidilmiştir (Rifaioğlu, 2014). Ancak 1957 tarihli imar planının kent dokusunu değiştiren ve sokak-avlu-ev ilişkisini zedeleyen bir düzen getirmesi sebebiyle geleneksel kent dokusu olumsuz yönde değişime uğramıştır (Özalp, 2008). 1975 yılında Gayrimenkul Eski Eserler ve Anıtlar Yüksek Kurulu'nun Antakya'nın korunması gerekli görülen eserler için gerekli önlemlerin alınması ve plan kararlarının bu amaca hizmet etmesi gerektiği yönündeki kararına bağlı olarak 1978 yılında yeni bir imar planı hazırlanmıştır (Ömeroğlu, 2006; Güzelmansur vd., 2007). Ancak bu plan da kentin tarihi dokusunu koruma yönünde başarılı olamamış ve 1987 tarihinde yeni bir imar planı devreye girmiştir. Bu planla 1. ve 3. Derece Arkeolojik Sit Alanları, bir Doğal Sit Alanı ve bir de Kentsel Sit alanı tanımlanmıştır (Rifaioğlu, 2014). Birçok medeniyet tarafından şekillenmiş kent, içerisinden geçen Asi Nehri'nin doğusunda kalan tarihi olayların ve kültürlerin oluştuğu alan, Hatay-Antakya Sit Alanı Koruma İmar Planı Uygulama Yönetmeliği'ne göre tanımlanmış ve 1990 yılında 638 sayılı kararı ile “Antakya Sit Alan Sınırları” son halini almıştır (Ömeroğlu, 2006). Tarihi kent dokusu olarak tanımlanan alan içerisindeki Gazipaşa Caddesi, 1. Derece Kentsel Sit Alanı ve 3. Derece Arkeolojik Sit Alanında bulunmaktadır. Çalışma alanı ve yakın çevresinde; camiler, kiliseler, hizmet alanları, ticaret bölgeleri, hamamlar, yaya yolları, taşıt yolları, sosyal tesisler ve meydanlar yer almaktadır (Şekil 2). Bunlar daha detaylı olarak kent imgesi analizi başlığı altında verilmiştir.

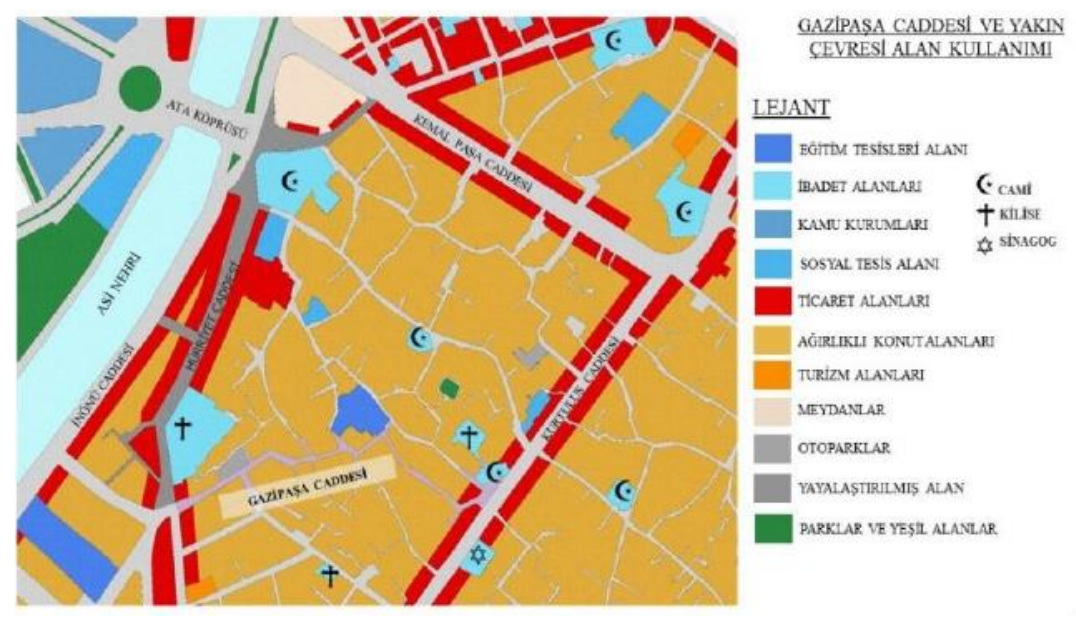

Şekil 2. Gazipaşa Caddesi ve yakın çevresi alan kullanımı (1/5000 ölçekli Koruma Amaçlı İmar Planı temel alınarak üretilmiştir).

Antakya Ortodoks Kilisesi'nin güneyi ve Kuseyri Konutu'nun doğusu ile başlayıp, Kurtuluş Caddesi’nde Sarımiye Camii ile son bulan; hâlihazırda yoğun kullanımı olan Gazipaşa Caddesi üzerinde, son yıllarda birçok işletme ve butik oteller açılmış, buna bağlı olarak alanın kullanım yoğunluğu daha da artmıştır. Alan içerisinde bulunan Fevzi Çakmak İlkokulu da caddenin sürekli işlek bir durumda olmasını ve etkin olarak kullanılmasını sağlamaktadır. Bununla birlikte Gazipaşa Caddesi, bir mahremiyet olgusu üzerinden tasarlanan, konut olarak kurgulanmış yapılar ve bu yapıların avlu duvarlarının çizdiği sınırlarla oluşan cadde ve sokaklardan oluşan kentsel doku içinde yer almaktadır. Birçok evin avlu katında sokağa açılan pencere bulunmaması, sokak istikametlerinin doğrusal olarak ilerlememesi ve çıkmaz sokaklar bulunması bunu doğrular niteliktedir.

Tarihi geçmişi bulunan bu evlerde yaşayan insanların farklı milletlerden ve dinlerden olması ve bir arada hoşgörü içinde yaşaması bu alanı kentin diğer yerlerinden ayıran en önemli özelliklerden biridir. Bu ortamın oluşmasındaki en büyük etken, evlerin mahreminde herkesin rahatça ve özgürce yaşayabiliyor olması bir sebep olarak gösterilebilir. Nitekim Emir (2006) cadde ve sokakların dar olmasına rağmen, konut mimarisinin ferah ve geniş olarak düşünülmüş olmasının gündelik hayatta buralarda yaşayan bireylerin rahatının ve huzurunun öncelikli olarak düşünüldüğünü ifade etmektedir. Ancak zaman içerisinde plan kararları doğrultusunda değişen fiziksel yapı ve fiziksel etmenlere bağlı olarak eskiyen mimari doku nedeniyle, tarihi dokudaki yapıların bir kısmı mülkiyet ve işlev değiştirmiştir. Bu yapılar çoğunlukla restoran, kafe ve pansiyon olarak yeniden düzenlenmiştir. Bunun sonucunda konut özelliği taşıyan ve mahremiyet duygusu üzerinden tasarlanan "Antakya Evleri” olarak anılan evlerin kimlikleri değişime uğramıştır. Bu bölgedeki tarihi sivil mimarlık örneğini 
yansıtan yapıların çoğu Kültür ve Tabiat Varlıklarını Koruma Bölge Kurulu tarafından tescillenerek korunmaktadır. Yenilenmesi ve sağlıklaştırılması düşünülen caddeler, sokaklar ve mıntıkalar Nazım İmar Planlarında belirtilse de bu değişim hareketi proje aşamasında kalmış ve uygulamaya geçilememiştir. Tarihi değeri olan yapıların restore edilmesinde öncelik anıtsal değer taşıyan öğelere verilmiş bazı tescilli yapılar ise restore edilmemiştir. Ayrıca daha önce yapılan bir çalışmada (Ömeroğlu, 2006) saptandığı üzere Sit alanında yaşayan halkın \%19'unun sit alanında yaşadığından haberdar olmamasından yola çıkarak toplumsal farkındalıkla ilgili bir sorun olduğunu söylemek mümkündür.

Elde edilen bu verilere ve gözlemlere dayanarak çalışma kapsamında başlıca sorunun "çalışma alanının sahip olduğu kültürel değerlerin ve alana özgü kimliğin yok olmaya başlaması" olduğu saptanmıştır. Çalışma hedefine bağlı olarak ana soruna sebep olan iki temel başlık seçilmiştir. Bunlardan ilki alanın ticari kazanımlara yönelik kullanılmaya başlanmasıdır. Ticari alanlara olan yakınlık sebebiyle işlek bir geçiş bölgesi olması ve çevresindeki anıtsal nitelikteki öğelerin bölgeye kattığ bir çekim merkezi haline getirmiş; bu sebeple alandaki konutlar ticari kullanım amacıyla el değiştirmiştir. Bu süreçte meydana gelen yapısal değişimlerin bir kısmı, giriş bölümünde de belirtilen, tarihi dokuyu korumaya yönelik yaklaşımlarla bağdaşmamaktadır. Ana soruna sebep olan temel başlıklardan diğeri, yönetimden sorumlu organların alanın korunması ve geliştirilmesi adına yeterli ve etkin girişimde bulunmamasıdır. Bu sorunlara bağlı olarak alanın genelinde gözlemlenen sorunlar; (a) geleneksel dokuyla uyumlu olmayan yeni yapı varlığı, (b) yeni işlevlerin beraberinde getirdiği araç trafiğinin artışı ve (c) metruk yapı sayısının artışıdır (Şekil 3).

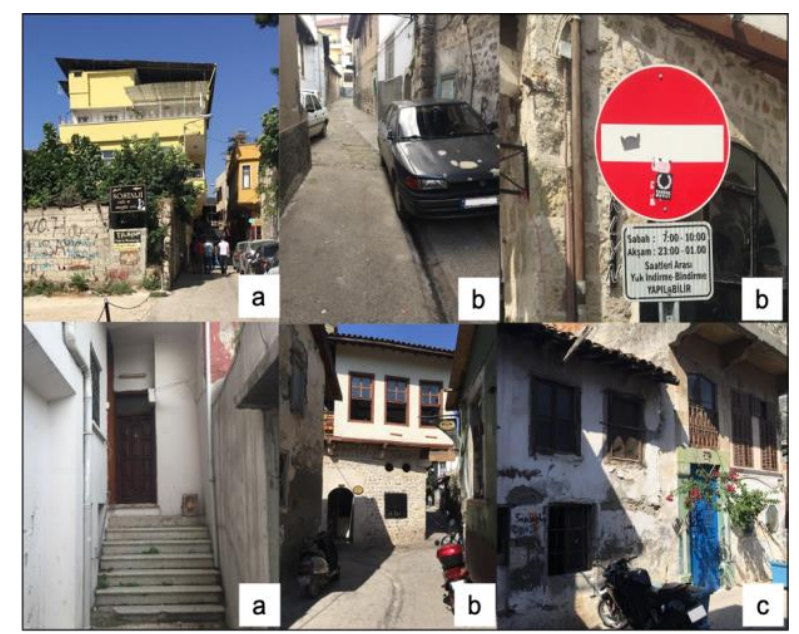

Şekil 3. Alanın genelinde gözlemlenen sorunlar

Ayrıca kentsel peyzaj unsurları temelinde; (d) yapı cephelerinde orijinal dokunun yıpranması ve bozulması, (e) sokak ve cadde döşemelerinin yıpranması, bozunumu, özgün yapısını kaybetmesi ve (f) donatı elemanlarının görsel peyzaj niteliğini bozacak biçimde olması olmak üzere sorunlar saptanmıştır (Şekil 4).

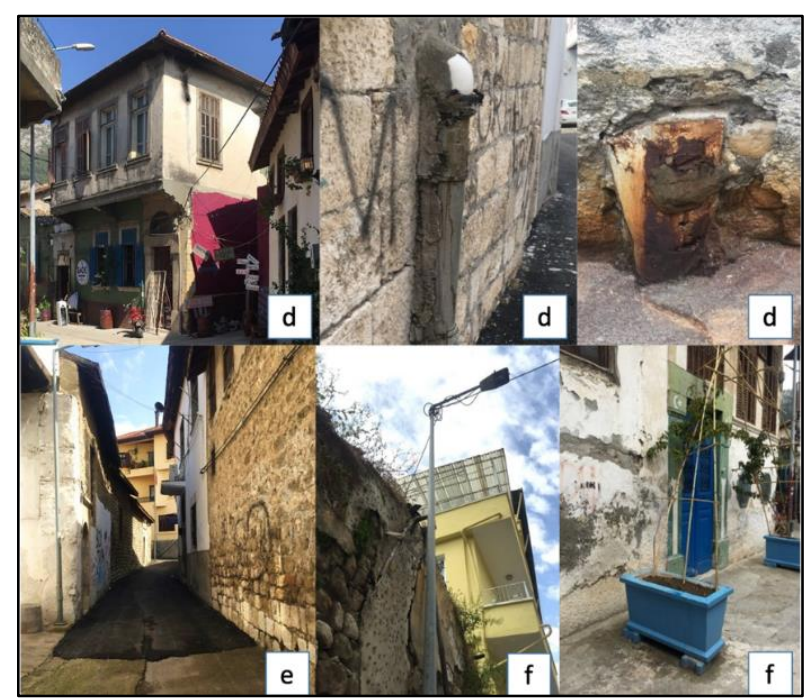

Şekil 4. Yapısal materyaller üzerinde gözlemlenen sorunlar 


\subsection{Kent Imgesi Analizi}

Antakya kenti içerisinde Gazipaşa Caddesi'nin mekânsal özelliklerinin daha iyi anlaşılması açısından Lynch'in (1960) çalışmasından yararlanılarak kent imgesi analizi yapılmıştır. Bu analizde beş temel değerlendirme unsuru bulunmaktadır. Bunlar; özgün odaklar, düğüm noktaları, sınırlar, bölgeler ve bağlantılardır. Gazipaşa Caddesi ve yakın çevresi bu 5 temel görsel algılama ögesi üzerinden analiz edilmiştir.

\section{Özgün Odaklar}

Çalışma alanı ve yakın çevresindeki noktasal referans kaynakları özgün odaklar olarak belirlenmiştir. Bu öğeler genellikle kolay tanımlanabilen basit fiziksel unsurlardır ve en önemli fiziksel karakteristikleri kolayca hatırlanan, biricik ve tek bir öğe olmalarıdır. Basitçe, yol tarif etmede referans olarak kullanılan öğeler olarak da tanımlanmaktadır (Lynch, 1960). Kent imgesi analizi özgün odakların belirlenmesinde bu tanımdan yola çıkılarak tarihi değeri bulunan yapılar ve mekânlar ile ibadet yapıları seçilmiştir. Kentin işlek iki caddesi olan Kurtuluş Caddesi ve Hürriyet Caddesi'ni birbirine bağlayan Gazipaşa Caddesi ve yakın çevresinde bulunan Habib-i Neccar Camii, Ulu Camii, Sarımiye Camii, Antakya Katolik Kilisesi, Antakya Ortodoks Kilisesi ve Antakya Musevi Sinagogu gibi ibadet yapılarının güçlü birer noktasal referans kaynağı olduğu gözlemlenmiştir. Özgün odakların seçilmesinde dikkat edilen diğer bir unsur da kentlilerin toplanma ve iletişim kurma alanları olan sosyal mekânlardır. I. Derece Kentsel Sit Alanı içerisinde bulunan Atatürk Parkı ile bulundukları yapıları tescilli olan Fevzi Çakmak İlkokulu ve Cindi Hamamı da kentlilerin yoğun olarak kullandıkları ve buna bağlı olarak sıklıkla referans olarak kullandığı noktalardır.

\section{Düğüm Noktaları}

Kent imgesi analizinde düğüm noktaları ve yol kavşakları hem bir kesişim noktası hem de bir yoğunlaşma alanı olan veya bazı karakteristiklerin yoğunlaştığı noktalardır. Bazen kentin bir bölümünden diğerine geçiş noktalarını oluştururken bazen meydan gibi kullanımların yoğunlaştı̆̆ nokta özelliklerini de göstermektedir (Lynch 1960). Kent meydanları halkın yoğun olarak kullandıkları en önemli etkileşim alanlarındandır (Sayın ve Çorbacı, 2019). Gazipaşa ve yakın çevresi düğüm noktalarının belirlenmesinde bu tanım dikkate alınmış, bu ölçütlere göre 4 düğ̈̈m noktası saptanmıştır. Özgün odaklarda taş binalar olarak belirtilen yapılar Eski Hatay Meclisi, Hatay Şehir Müzesi, PTT Antakya Merkez Müdürlüğü, Hatay Büyükşehir Belediyesi, Ziraat Bankası binalarıdır. Bu binalar arasında kalan alan, Atatürk heykelinin bulunduğu Cumhuriyet Meydanı'dır. Küçük ölçekli bir meydan olan bu nokta araç ve yaya yoğunluğun gözlemlendiği bir nokta olmasının yanında, eski kent ile yeni kenti birbirinden ayıran bir geçiş noktası özelliği de taşımaktadır. Bu kapsamda Cumhuriyet Meydanı'nın yaya ve araç yoğunluğunun aktığı nokta 1 numaralı düğüm noktası olarak belirtilmiştir.

Araç trafiğine kapalı dar sokaklara sahip Gazipaşa Caddesi ve yakın çevresinde bulunan ticari işletmelere, okullara ve dini yapılara servisin sağlanması ağırlıklı olarak bu bölgeler üzerinden sağlanmaktadır. Gazipaşa Caddesi'nin sonunda belirtilen 2 numaralı düğüm noktası, yaya yolu ve araç yolunun kesiştiği bölgeleri belirten düğ̈̈m noktasıdır. Buna ek olarak araç trafiğine kapalı Hürriyet Caddesi ve çevresindeki alanlara ulaşım sağlayan toplu taşıma araçlarının duraklarının Kurtuluş Caddesi üzerinde bulunması ve Gazipaşa Caddesi’nin bir geçiş bölgesi konumunda olması 3 numaralı alanın düğüm noktası olarak gösterilmesindeki sebeplerdir. Kemalpaşa Caddesi ve Kurtuluş Caddesi'nin birleştiği noktada belirtilen 4 numaralı düğüm noktası, çift taraflı akan araç trafiğinin kesişim noktasında bulunması ve Anadolu'nun ilk camisi olan Habib-i Neccar Camii'nin yakınında olması sebebiyle işlek araç ve yaya trafiğine sahiptir (Şekil 6).

\section{$\underline{\text { Sinirlar }}$}

Sınırlar/kenarlar, kullanıcılar tarafından ulaşım aksları gibi algılanmayan doğrusal öğelerdir. Her zaman olmamakla beraber genellikle iki tür alanı birbirinden ayırırlar ve yanal referans görevi üstlenirler (Lynch 1960). Kent imgesi analizinde caddeleri tanımlayan konutların avlu duvarları sınırlar olarak belirtilmiştir. Birbirini izleyen avlu duvarları bir koridor oluşturarak caddede yönlendirici etki yaratan kenarlar halini almışlardır (Şekil 5). 


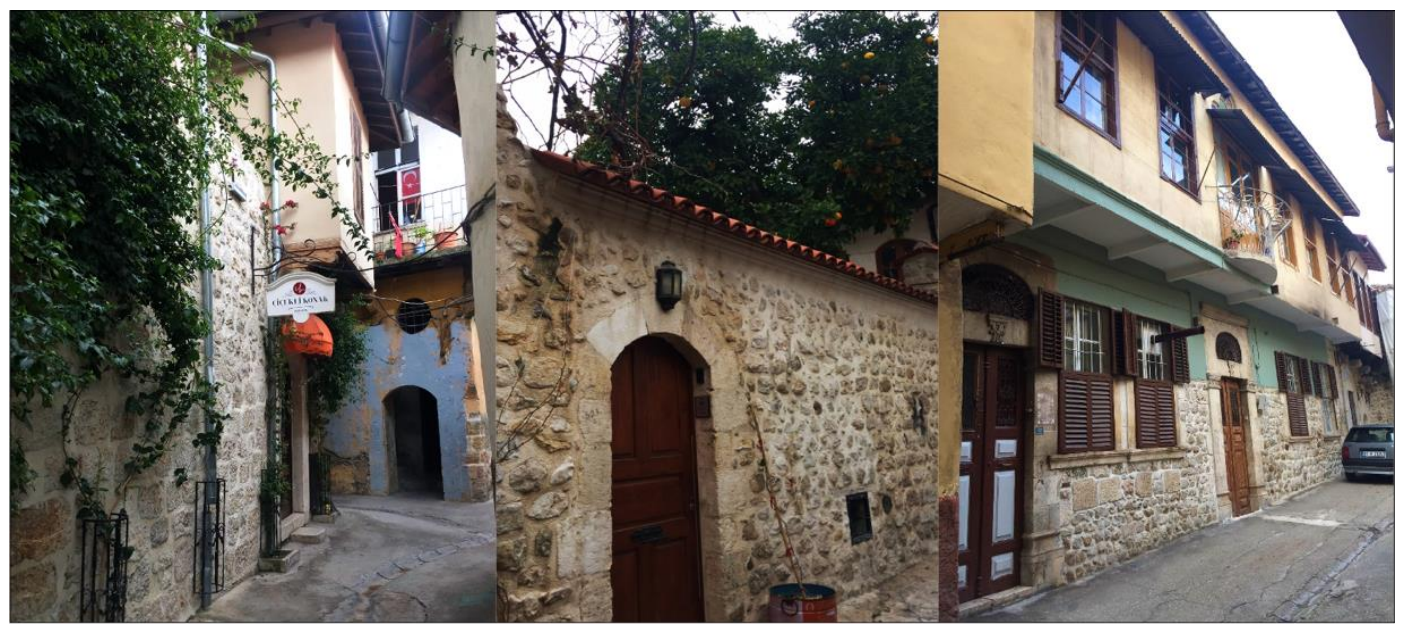

\section{$\underline{\text { Bölgeler }}$}

Şekil 5. Sınırları oluşturan yapı duvarları (Orijinal, 2017).

Lynch (1960) bölgeleri, diğer öğelere nazaran daha büyük kent parçalarını ifade eden, yön bulmak için kullanılmanın yanı sıra, kent yaşamının deneyimlenmesinde önemli ve tatmin edici birer öğe; sembol, ayrıntı, fizik, yapı tipleri, doku, alan, onarım durumları gibi birçok farklı bileşene sahip özellikleri barındırabilirler konut alanları olarak tanımlanmıştır. Gazipaşa Caddesi ve çevresindeki yapı karakteri, formu, tarihi dokusu, onu kentin diğer yerlerinden ve diğer kentlerden ayıran özellikleri bakımından bölgeler olarak belirtilmiştir. Bu bölgede bulunan birey bulunduğu alanı kentin diğer bölgelerinden kolayca ayırt edebilir. Dolayısıyla çalışma alanın tamamı ticari ve konut dokusunun beraber bulunduğu tek bir bölge olarak kabul edilmiştir.

\section{$\underline{\text { Bağlantılar }}$}

Kent imgesi analizinde bağlantılar; alanlar sokaklar, caddeler, kanallar, yaya yolları, demiryolları olabilen pek çok kişinin imgesinde baskın olan yerlerdir (Lynch 1960). Gazipaşa Caddesi ve yakın çevresindeki yaya ve araç yolları bağlantılar şeklinde gösterilmiştir. Sonuç olarak Şekil 6 imge bileşenlerini göstermektedir.

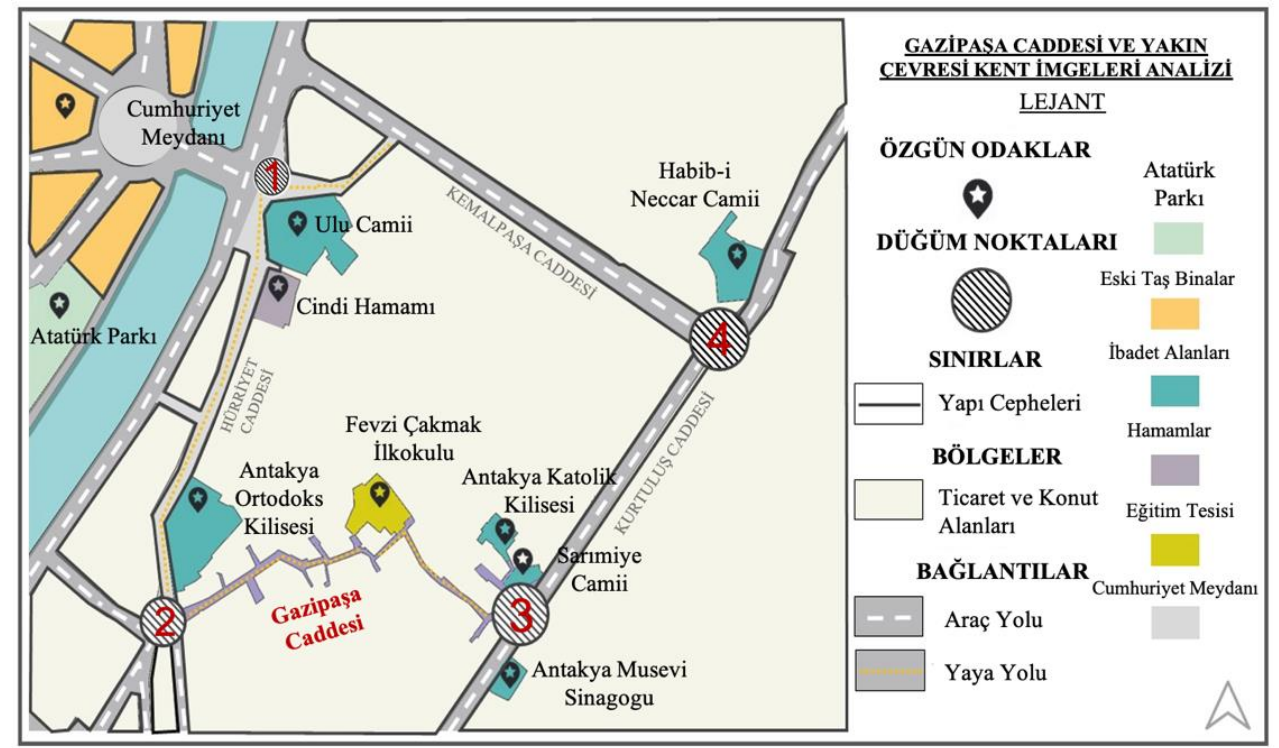

Şekil 6. Gazipaşa Caddesi ve yakın çevresi kent imgeleri analizi.

\subsection{Anket Bulguları}

Çalışma alanını daha iyi tanımak ve alanı kullanan bireylerin görüşlerini almak amacıyla gerçekleştirilen anket çalışmasında bulgular frekans analizi ile belirlenmiştir. Çalışma alanında farklı yaş, eğitim durumu ve mesleğe sahip toplam 50 kişi ile anket çalışması yapılmıştır. Ankete katılanların \%48'i kadın, \%52'si erkektir. Alan kullanımında cinsiyet verileri eşit dağılım göstermektedir. Katılımcıların \%42'si üniversite mezunu, geri kalanı 
ise ilk ve orta öğretim mezunudur. Çalışma durumuna katılımcıların \%14'ü memur-işçi, \%16'sı emekli, \%24'ü öğrenci ve \%30’u diğer meslek olarak cevap vermiştir.

Katılımcılara yöneltilen “Alana nasıl ulaşıyorsunuz?” sorusuna, \%44 oranıyla “yaya olarak” cevabı verilmiştir. Alanın araç trafiğine kapalı olması ve çevresinde alanı ziyaret eden insan sayısını karşılayacak kapasiteli otopark olmaması sebebiyle bu oranın yüksek olduğu yorumu yapılabilir. "Alana kendi aracınızla gelmeniz halinde nerelere park ediyorsunuz?" sorusuna ankete katılanların \%60’1 "bulunan boș bir yere" cevabını verirken \%24 "alana gelirken yol üzerine" demiştir. Yalnızca \%16'lık bir kesim "yakınlarda bir otoparka" cevabını tercih etmiştir. Yapılan anket kapsamında katılımcılara alanın fiziksel özelliklerine dair memnuniyetleri sorulmuştur. Alanı kullanan katılımcıların yarısından fazlası $\% 60$ oranında, Gazipaşa Caddesi'nin yaya yoğunluğunu karşılayabildiği görüşündedir. "Yeterli oturma ve dinlenme alanı var mı?" sorusuna ise katılımcıların \%86'sı "hayır" olarak cevap vermişlerdir. Bununla birlikte caddenin dar olmasından dolayı (Şekil 7), mekânı görsel olarak algılayabilecek ve etkin deneyimleyebilecek bir oturma ve dinlenme alanı tasarlanması fiziksel olarak zor görünmektedir.

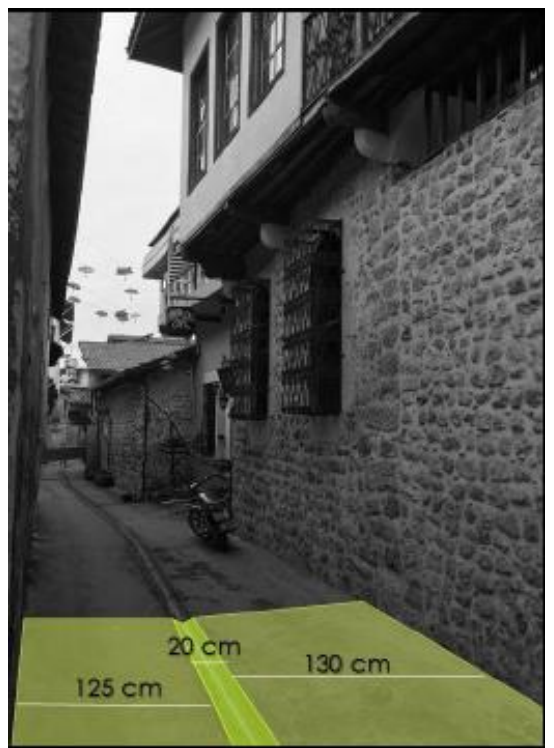

Şekil 7. Gazipaşa Caddesi genişlik durumu (Orijinal, 2017).

Benzer biçimde alandaki donatı elemanları da katılımcılar tarafından yetersiz bulunmuş, yalnızca \%8'i yeterli olduğunu ifade etmiştir. Hem gündüz hem gece kullanım açısından ise katılımcıların büyük bir kısmı (\%78) alanı "güvenli" bulmaktadır.

Katılımcıların yarısına yakın bir oranı (\%42) alanı sosyal aktivite amacıyla kullandıklarını belirtmişlerdir. Bu cevab1 \%16 ile konut ve iş amaçlı, \%14 ile tarihi mekân ziyareti takip etmektedir.

Alandaki değişim hakkındaki görüşlerini sorgulamak üzere "Alanda yapılması muhtemel herhangi olumlu bir değişim, kentin genel kimliği üzerinde etkili olur mu?" sorusuna katılımcıların \%52'si “etkili olur”, \%42'si "kısmen etkili olur" yanıtı verirken yalnızca \%6'lık kısım "etkisiz” cevabını vermiştir. Gerçekleşmesi muhtemel bir değişime yönelik olarak katılımcıların \%38'si “oturma- dinlenme”, \%28'si "var olan kültürel değerlerin korunması”, \%26'sı “otopark yapılması” ve \%8'i “iş olanaklarının artırılması” taleplerini belirtmişlerdir.

Alanın görsel peyzaj değerinin çekiciliğini (estetik) katılımcıların \%42'si orta, \%26'sı ise zayıf olarak tanımlamıştır. Yalnızca \%16 oranında bir kesim alanın estetik açıdan çok iyi durumda olduğu cevabını vermiştir. Dolayısıyla tarihi dokunun estetik değeri ankete katılanlar tarafından yeterli bulunmamaktadır.

\subsection{GZFT Analizi}

Daha önceki bölümlerde elde edilen veriler doğrultusunda kentin tarihi kimliğinin önemli bir parçası olan Gazipaşa Caddesi temel sorun çerçevesinde kentin kimliği ve kültürel değerlerine dayanarak GZFT analiziyle değerlendirilmiştir. Değerlendirmede güçlü yönler ve firsatlar ile zayıf yönler ve tehditler bir arada ele alınarak iki bölümde incelenmiştir. Çalışma alanına ilişkin olumlu ve olumsuz özellikleri Tablo 1'de verilmiştir. 
Tablo 1. Çalışma alanına ilişkin GZFT analizi.

\begin{tabular}{|c|c|}
\hline GÜÇLÜ YÖNLER VE FIRSATLAR & ZAYIF YÖNLER VE TEHDİTLER \\
\hline $\begin{array}{l}\text { Çalışma alanı ve yakın çevresinde farklı } \\
\text { dönemlere ait tarihi ve kültürel değer taşıyan } \\
\text { yapıların varlığı. }\end{array}$ & $\begin{array}{l}\text { Alanda yaşayanların tarihi çevre korumanın } \\
\text { önemi konusunda yeteri kadar bilgili olmaması. }\end{array}$ \\
\hline $\begin{array}{l}\text { Kendine özgü mimari karakterde yapıların } \\
\text { bulunması. }\end{array}$ & $\begin{array}{l}\text { Alandaki tarihi yapıların, döneminin özelliklerini } \\
\text { yansıtan nitelikte restore edilmemiş olması. }\end{array}$ \\
\hline Alanın koruma statüsünün bulunması. & $\begin{array}{l}\text { Tarihi yapıların cephelerinde reklam afişleri, } \\
\text { panolar, telefon ve elektrik kablolarının alanda } \\
\text { yarattığ görsel kirlilik. }\end{array}$ \\
\hline $\begin{array}{l}\text { Tarihi kentsel sit alanının sürekli ziyaretçisi } \\
\text { olması. }\end{array}$ & $\begin{array}{l}\text { Renk, kullanılan yapı malzemeleri, mimarisi ve } \\
\text { kat yüksekliği ile yöreye özgü geleneksel konut } \\
\text { tipiyle bağdaşmayan yeni yapı varlığı. }\end{array}$ \\
\hline $\begin{array}{l}\text { Kent içinde tarihi değer taşıyan alanları } \\
\text { kullanmaya yönelik talebin olması. }\end{array}$ & $\begin{array}{l}\text { Cadde üzerinde bulunan işletmelerin, alanın } \\
\text { tarihi değerlerini ve ögelerini yansıtmayan kimlik } \\
\text { karmaşası. }\end{array}$ \\
\hline $\begin{array}{l}\text { Yerli yatırımcıların bölgeyi sahiplenmiş } \\
\text { olması. }\end{array}$ & $\begin{array}{l}\text { Tarihi bölgenin korunması adına yeterince } \\
\text { yatırım yapılmaması. }\end{array}$ \\
\hline $\begin{array}{l}\text { Yerleşme düzeni açısından merkezi bir } \\
\text { konumda bulunmasi. }\end{array}$ & $\begin{array}{l}\text { Alandaki donatı ve dinlenme/gezmeye yönelik } \\
\text { fasilitelerin yetersiz olması. }\end{array}$ \\
\hline $\begin{array}{l}\text { Kullanıcıların alanda kendini güvenli } \\
\text { hissetmesi. }\end{array}$ & $\begin{array}{l}\text { Alana araçla ulaşımı destekleyen mekânsal bir } \\
\text { organizasyonun bulunmaması. }\end{array}$ \\
\hline $\begin{array}{l}\text { Çalışma alanının da dâhil olduğu tarihi } \\
\text { dokuyu ele alan farklı meslek } \\
\text { disiplinlerinden çalışmalar olması. }\end{array}$ & $\begin{array}{l}\text { Kentin hızlı büyümesi sonucunda artan araç } \\
\text { trafiği, kontrolsüz yapılaşma gibi nedenlerle } \\
\text { alanın çevresel kullanım kaynaklı baskılara } \\
\text { maruz kalıyor olması. }\end{array}$ \\
\hline & $\begin{array}{l}\text { Kentsel peyzaj ögelerine müdahaleler nedeniyle } \\
\text { su drenajı gibi geleneksel altyapı çözümlerinin } \\
\text { zarar görmüş olması. }\end{array}$ \\
\hline
\end{tabular}

Gazipaşa Caddesi'nin, kent tarihinin çok eski dönemlerinden beri farklı milletlere ait şekillenen dokusuyla kent kimliği açısından değerli bir bölge olduğu açıktır. Yapılan analizde çalışma alanı ve yakın çevresinin sahip olduğu zengin kültürel değerlerin gerek kentin tarihi kimlik değerini oluşturma gerekse farklı sektörler yönünden (turizm ve ticaret) geniş fırsatlar yaratabileceği saptanmıştır. Buna karşın uzun yıllardır süregelen yönetim ve planlama süreçlerinde, var olan tarihi özellikleri korumaya gerekli özenin gösterilmemiş olması en büyük tehditlerden biridir. Ayrıca tescilli yapıların restore edilip turizme kazandırılması (Antakya Belediyesi, 2019), tarihi dokunun özgün değerini risk altında bırakmaktadır.

\section{Sonuç ve Öneriler}

Kentin hızla büyümesine bağlı olarak; tarihi kent merkezlerinde giderek artan nüfus yoğunluğu, buna bağlı olarak artan araç trafiği sorunları, mülk sahiplerinin geleneksel dokuları terk etmesi ile bu alanlarda oluşan sosyal değişimler ve korumaya yönelik plan ve uygulama çalışmalardaki yetersizlikler tarihi dokuyu değiştirmiş ve geçmişin izlerini algılanamaz duruma getirmiştir. Tarihi kentlerin kimliklerini kaybetmeye yönelik bir sürece girmesinin engellenmesi ve kaybetmekte olduğu kimlik öğelerini tekrar kazanması için; kentin sağlam formunun, dokusunun ve yapıların birlikte ele alınması gerekmektedir. Bu dokulara veya yapılara yeni işlevler yüklenecekse tarihi kentin karakteriyle uyumlu olması sağlanmalıdır (Şahin, 2010). Kuşkusuz, tarihi kent peyzajı önemli bir turizm değeri ortaya koymaktadır. Bununla birlikte çalışma alanı özelinde, geçmiş dönemlerde konut alanı olarak biçimlenen dar ve çıkmaz sokaklar ile dışarı kapalı, geniş avlulu yapı karakterinin turizm amaçlı kullanım biçimiyle uygunluğu tartışılmalı, fiziksel müdahalenin ne ölçüde olacağı çok disiplinli ve bütüncül bir yaklaşımla kurgulanmalıdır. Kuban'a (2000) göre koruma, yapının tekil olarak değil, çevresi ile birlikte ele alınarak korunmasıyla anlamlı hale getirilmelidir. Korumanın kapsamı, yapı ölçeğinden başlayarak, sokak, mahalle, kent ve bölge ölçeğine doğru tüm çeşitleri kapsamalıdır (Kale, 2011). Ayrıca toplumsal süreçlerin ve sosyal yapının içinde bulunduğu durum ve geçirdiği değişim de mekândan bağımsız düşünülmemelidir.

Antakya'nın tarihi kent dokusunun ve kimliğinin korunması, yerleşmenin geleneksel mimarisi ve kültürel peyzaj mirasının gelecek nesillere aktarılmasını mümkün kılmak amacıyla örnek alan Gazipaşa Caddesi bu miras değerinin farkına varılması korunması ve geliştirilmesi bağlamında önemlidir. Antakya kentinin kimliğinin 
devamının sağlanması ve sürdürülebilmesi için çalışma kapsamında yapılan analizler ile anket çalışmasından elde edilen bulgular ele alınmış ve yapılan analizlere dayalı olarak tarihi dokuda kimliği geri kazanmaya yönelik geliştirme ve iyileştirmeye dayalı birtakım öneriler geliştirilmiştir. Bu bağlamda alana ilişkin öneriler sınıflandırılarak belirtilmiştir.

\section{- $\quad$ Yapısal Düzenlemelere İlişkin Öneriler}

$\checkmark \quad$ Çevrede görüntü kirliliğine sebep olan tüm cephelerde iyileştirme çalışmaları yapılmalıdır. Tarihi doku ile uyumlu renklerde olmayan yapıların üzerindeki sıvalar kazınarak örme taş duvarlarla oluşturulmuş cepheler ortaya çıkarılmalıdır. Örme taş cepheyle oluşturulmamış cephe boyaların renk seçimleri de alanın genel siluetindeki renklerle uyumlu olmalidır.

$\checkmark \quad$ Mevcut yollar beton ve yer yer asfalt ile kaplanmıştır. Eğimli döşenen taş kaplamanın üzerinin evlerin giriş kotlarıyla aynı seviyede kaplanmasıyla, ani yağışlar yaşanan Antakya'da fazla suyun ortaya doğru akmasını sağlayan ve suyun evlerden içeri girmesine engel olan sistem de ortadan kalkmıştır. Bu sebeple cadde boyunca mevcuttaki beton yollar kaldırılarak, tarihi Antakya sokaklarının eski parke taşlarıyla kaplı haline dönüştürülmesi için yöreye özgü mimari tasarımları içeren sokak projeleri hazırlanması gerekmektedir. Bu projelerin hazırlanmasında yağmur suyu yönetimine uygun olarak geçirgen yüzeylerin kullanılması ve yağmur suyunun depolanması gibi sistemlerin gerekliliği göz önünde bulundurulmalıdır.

$\checkmark$ Yıkılmaya yüz tutmuş metruk yapılar, anıt, çeşme, hamam, konut gibi mimari örnekler üzerinde sağlamlaştırma, onarım, yenileme ve temizleme işlemleri yapılmalıdır.

$\checkmark$ Geleneksel yapıların kat yükseklikleri dikkate alınarak, mevcut tarihi doku ve mimariye uygun, mevcut çevre ölçeğini dikkate alan ve tarihi kentsel peyzaj değerlerine katkıda bulunan düzenlemeler gerçekleştirilmelidir.

$\checkmark \quad$ Her türlü yapısal müdahale denetlenebilir olmalı, gerektiğinde hızlı müdahale edilmelidir.

\section{- Kentsel Donatı Elemanlarına İlişkin Öneriler}

Araştırma bulgularında belirtilen kullanıcı anket değerlendirmelerine dayalı olarak donatı elemanlarının yetersiz bulunması göz önünde tutulduğunda, kentsel donatı elemanları konusunda, Gazipaşa Caddesi'nde mekânın tanınırlığının artıran, kent estetiğine ve işlevine katkısı olan, mekânın özgün kimliği ile bütünleşen tarihi dokuya uyumlu donatı elemanlarında düzenlemelere ihtiyaç olduğu sonucuna varılmıştır.

$\checkmark$ Caddede kullanılacak aydınlatma elemanları sokağın mekânsal yapısına uygun olarak seçilmelidir. Kullanılabilecek aydınlatmalar, avluyu aktif olarak kullanmaya devam eden kullanıcıların günlük yaşamını da göz önünde bulundurularak avlu duvarını aşmayacak yükseklikte olmalıdır. Gazipaşa Caddesi üzerinde bulunan kapı, pencere işlemeleri referans alınarak çizilen aydınlatma elemanları önerilmiştir (Şekil 8). Caddenin geniş olduğu kısımlarda aydınlatma direği ile kullanılan aydınlatma elamanını, caddenin dar kısımlarında duvara monte edilerek kullanılması önerilebilir.

$\checkmark$ "Yeterli oturma ve dinlenme alanı var mı?" sorusuna katılımcıların \%86'sının "hayır" cevabı vermesine istinaden, evrensel tasarım ilkeleri göz önünde bulundurularak engelli ve yaşlı bireyler de düşünülmeli; caddenin belirli noktalarında oturma birimleri konumlandırılmalıdır.

$\checkmark$ Mevcut yapıların üzerinde bulunan reklam/tanıtım amaçlı tabelalar kaldırılmalı, kullanılacak tabelalar için belirli bir malzeme ve boyut belirlenerek bir şablonun alanda kullanımı yaygınlaştırılmalıdır. Asılacak yeni yönlendirme levhalarının mevcuttaki haliyle cepheye paralel değil, dik asılmasıyla sokakta algılanabilirliği arttırılmalıdır (Şekil 8).
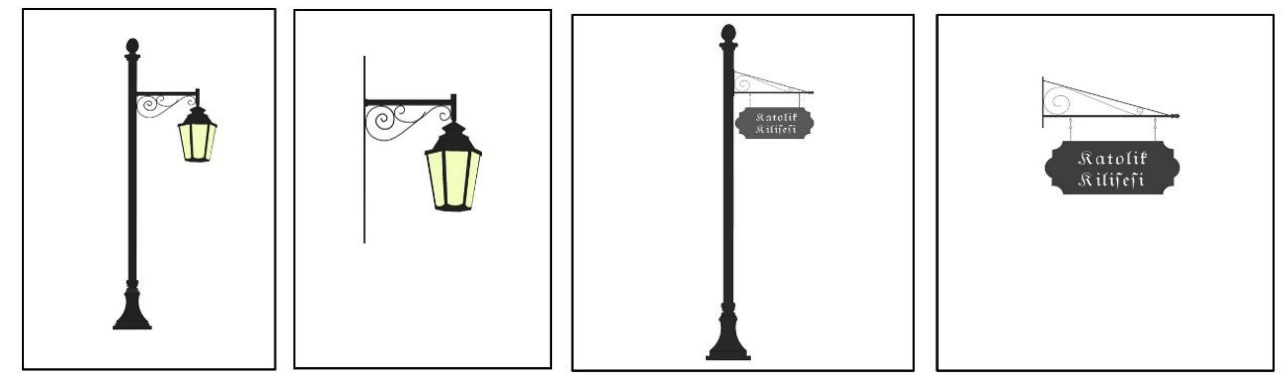

Şekil 8. Aydınlatma elemanı önerisi/ Yönlendirme-Bilgilendirme levhası önerisi (Orijinal, 2018).

- Canlı Peyzaj Unsurlarına İlişkin Öneriler

$\checkmark$ Gazipaşa Caddesi ve yakın çevresindeki konutlar, kente kimlik katan önemli unsurlardır. Bu yapıların gelecek kuşaklara aktarımının yalnızca yapısal düzenlemelerle değil, peyzaj unsurlarının korunması ve 
geliştirilmesiyle de sağlanabilir (Şekil 9).

$\checkmark$ Tarihi yapıların oluşturan taş malzemenin bozunumunun önüne geçilmesi için duvarlarda yayılış gösteren bitkiler temizlenmelidir.

$\checkmark$ Konut avlularında gerçekleştirilecek olan peyzaj düzenlemeleri kontrollü olmalı, avlunun karakterini yansıtacak tasarım özellikleri korunmalıdır. Yapılarda bulunan havuz, seki, orijinal yer döşemeleri, fanus ve kuş takaları orijinal haliyle muhafaza edilmeli, tahrip olanların da yenileme çalışmaları yapılmalıdır.

$\checkmark \quad$ Kentsel dokuyla uyumlu, renk, form ve doku özellikleri gösteren bitki taksonları tercih edilmelidir. Alanda kullanılacak bitki taksonların doğal türler olması ekosistemlerin sürdürülebilirliği açısından önemlidir (Çorbacı vd., 2020). Bu kapsamda bu türlerin kullanılması teşvik edilmeli, mevcut bitki varlığının sürdürülebilirliği sağlanmalı, gerekli bakım ve budama çalışmaları yapılmalıdır.

$\checkmark$ Mevcut bitki varlığının devamı sağlanmaya çalışılmalı ve bitki varlığı caddede de görülebilir hale getirilmelidir. Gazipaşa Caddesi'nde restore edilmiş yapıların kullandığı bitkisel çözümlemeler alanda yaygınlaştırılmalıdır (Şekil 9).

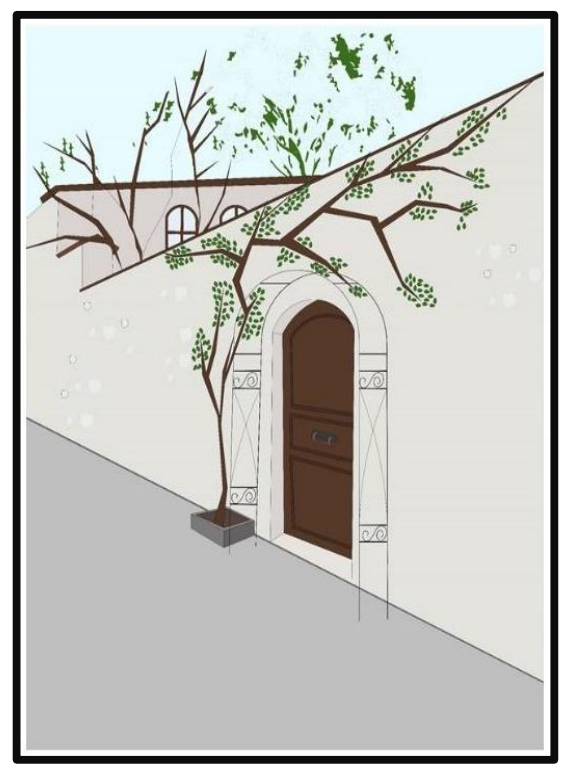

Şekil 9. Gazipaşa Caddesi’nde restore edilmiş yapıların kullandığı bitkisel çözümlemeler (Orijinal, 2018).

\section{- Korumaya İlişkin Öneriler}

$\checkmark$ Alanla ilgili veri toplamada kaynak yetersizlikleri (eski verilerin güncellenmemiş olması) bulunmaktadır. Bu bilgiler, ilgili meslek disiplinleri ile güncellenmeli ve erişilebilir olmalıdır.

$\checkmark$ Alandaki ticari işletmelerin sayısı sınırlandırılmalıdır. Yıpranmış ve zarar görmüş tescilli yapıların restore işlemlerinin karşılayamayacak mülk sahipleri yerine restore işlemleri yerel yönetim ve kalkınma ajanslarının iş birliği ile gerçekleştirilmeli, daha fazla mülk sahibinin alandan gitmesinin önüne geçilmelidir.

$\checkmark$ Tek tip özellik gösteren işletmeler yerine Antakya'nın kültürel değerlerini yansıtan özellikte işletmeler olmasına önem verilmelidir. UNESCO Gastronomi Şehri Hatay'ın zengin mutfak öğelerini sergileyen restoran, kentin ekonomik anlamda kalkınmasına yarar sağlayacak konaklama tesisleri ile Antakya evlerinin avlu, bitki türleri, döşeme, malzeme gibi tüm kendine has özelliklerini barındıran üç dinin bir arada yaşadığı tarihsel süreçleri içeren bilgiler barındıran müze evler önerilmektedir.

$\checkmark$ Alanın büyük oranda özel mülkiyete ev sahipliği yapması ve alanın en çok sosyal aktivite sebebiyle kullanılması, burada yapılacak değişimler konusunda halkın katılımını zorunlu kılmaktadır. Gazipaşa Caddesi ile ilgili geliştirilen plan ve projeler sergilerle halka tanıtılmalı, broşürlerle halkın bilgilendirilmesi sağlanarak katılımcı bir süreçle kullanıcı fikirleri de projelere dâhil edilmelidir.

$\checkmark$ Gazipaşa Caddesi'nin geçmiş dokusunun korunması, yaşatılması ve geliştirilmesinde dikkat edilmesi gereken diğer nokta kentlilerin yaşadıkları alandaki özgün değerlerin bilincinde olmasıdır. Kültür ve doğanın tükenebilir bir kaynak olduğu anlatılmalı, kentin genelinde koruma bilincinin oluşması ve alanın sahiplenilmesi için eğitimler verilmelidir. Bu eğitimlerde korumanın ne olduğu, dokunun korunmaması durumunda kentte yaşanacak olumsuz durumların neler olacağı konularına ışık tutmalıdır.

$\checkmark \quad$ Koruma Amaçlı İmar Planı, Eski Antakya Evleri’nin gelecek nesillere olduğu gibi aktarılması adına yeniden düzenlenmeli ve alan daha katı kurallarla korunmalıdır. Gazipaşa Caddesi, yakın çevresini de içeren tarihi kent bütüncül bir planlama anlayışıyla ele alınmalıdır. 
Kentin simgeleri olan tarihi yapıların yerini her geçen gün yeni yapılar almaya başlamıştır. Kentin her bölgesinde hissedilmeye başlanan dönüşümlerin tarihi kent merkezlerinden uzak tutulması ve bu alanların sahip oldukları kimliğin korunup geleceğe aktarılması adına önemlidir. Korumanın kalıcı olması ve uygulanabilir olması, bütüncül ve çok paydaşlı planlama ve tasarım yaklaşımlarıyla mümkün olacaktır. Bir kentin benliği ve kendini ifade ediş biçimi bu şekilde bir sonraki kuşaklara aktarılabilir.

\section{Bilgilendirme}

$\mathrm{Bu}$ çalışma Ankara Üniversitesi, Fen Bilimleri Enstitüsü, Peyzaj Mimarlığı Anabilim Dalı'nda tamamlanan "Tarihi Kent Kimliği Kapsamında Kamusal Açık Alanlar: Antakya Gazipaşa Caddesi Örneği” isimli Yüksek Lisans tezinden üretilmiştir.

\section{Kaynaklar}

1. Antakya Belediyesi (2019). 2020-2024 Stratejik Plan1. http://www.antakya.bel.tr/Files/2020_ilanlar/2020-. 2024\%20antakya\%20belediyesi\%20stratejik\%20plan.pdf, (28.02.2021).

2. Arabacıŏlu, F. P., Aydemir, I. (2007). Tarihi Çevrelerde Yeniden Değerlendirme Kavramı. Megaron, 2(4), 204-212.

3. Cresswell, T. (2004). Place: A Short Introduction. Blackwell Publishing, Oxford.

4. Çorbacı, Ö L., Abay, G., Oğuztürk, T, Üçok, M. (2020). Kentsel Rekreasyonel Alanlardaki Bitki Varlığı; Rize Örneği/Plant Existence in Urban Recreational Areas; Rize Example. Düzce Üniversitesi Orman Fakültesi Ormancılık Dergisi, 16 (2), 16-44.

5. Demir, A. (1996). Çağlar İçinde Antakya. Akbank Yayınları, İstanbul.

6. Emir, H. C. (2006). Antakya Kuseyri Evi Restorasyon Projesi. Yüksek Lisans Tezi, İstanbul Teknik Üniversitesi, İstanbul, Türkiye, $266 \mathrm{~s}$.

7. Garagnani, S., Arteaga, J., Bravo, L. (2016). Understanding Intangible Cultural Landscapes-Digital Tools as A Medium to Explore the Complexity of The Urban Space. Parametricism vs. Materialism: Evolution of Digital Technologies for Development [8th ASCAAD Conference Proceedings, London (United Kingdom) 7-8 November 2016, pp. 431-436.

8. Güzelmansur A., Salıcı A., Altunkasa, M. F. (2007). Kentleşme ve Kentsel Yaşam Niteliği Arasındaki Etkileşimlerin Dış Mekânlar Açısından İrdelenmesi: Antakya Örneği. 38. ICANAS Uluslararası Asya ve Kuzey Afrika Çalışmaları Kongresi, 10-15 Eylül 2007, ss. 511-524, Ankara.

9. Hatami, M. (2013). Tarihi Kent Merkezlerinin Koruma Sorunları, Urmiye Tarihi Kent Merkezi Üzerine Bir Araştırma. Yüksek Lisans Tezi, İstanbul Teknik Üniversitesi, İstanbul, Türkiye, $165 \mathrm{~s}$.

10. ICOMOS (2011). Tarihi Kentlerin ve Kentsel Alanların Korunmasıv ve Yönetimiyle İlgili Valetta İlkeleri. Erişim Adresi: http://www.icomos.org.tr/Dosyalar/ICOMOSTR_tr0592931001536912260.pdf, (01.06.2017).

11. Kale, B. (2011). Tarihsel Kent Peyzajlarının Korunması, Hamamönü Örneği. Yüksek Lisans Tezi, Ankara Üniversitesi, Ankara, Türkiye, 109 s.

12. Kaymaz, I. (2013). Urban Landscapes and Identity. Advances in Landscape Architecture (Ed. Murat Özyavuz). IntechOpen. Crotia.

13. Keleş, R. (1980). Kentbilim Terimleri Sözlüğü, Türk Dil Kurumu Yayınları, Sevinç Basımevi, Ankara.

14. Kurtar, C., Somuncu M. (2013). Kentsel Kültürel Mirasın Korunması ve Sürdürülebilirliği. Ankara Araştırmaları Dergisi, 1(2), 35-47.

15. Lynch, K. (1960). The Image Of The City. The Technology Press \& Harvard University Press, Cambridge.

16. Ömeroğlu, C. (2006). Antakya Kentinin Özgünlüğü ve Günümüz Koruma Sorunlarının Antakya Kentsel Sit Alanında İrdelenmesi. Yüksek Lisans Tezi, Gazi Üniversitesi, Ankara, Türkiye, 215 s.

17. Özalp, D. (2008). Tarihi Kent İmajının Korunmasında Kentsel Tasarım: Antakya Örneği. Uzmanlık Tezi, Kültür ve Turizm Bakanlığı Kültür Varlıkları ve Müzeler Genel Müdürlüğü, Ankara.

18. Relph, E. (1976). Place and Placelessness. Pion, London.

19. Rifaioğlu, M. N. (2014). The Historic Urban Core of Antakya Under the Influence of the French Mandate, and Turkish Republican Urban Conservation and Development Activities. Megaron, 9(4), 271-288.

20.Sayın, G., Çorbacı, Ö. L. (2019). The Development of Squares from the Past to Present, Mehmet Dalkılıç (Ed.), International Researches in Health and Natural Sciences, pp. 63-77, ISBN: 978-605-7809-42-80-3. Gece Kitaplı̆̆ 1 , Ankara.

21.Şahin, N. (2010). Kent Kimliği ve Değişim Sürecinin Kayseri Kenti Örneğinde İrdelenmesi. Yüksek Lisans Tezi. Mimar Sinan Güzel Sanatlar Üniversitesi, İstanbul, Türkiye, 174 s. 
22. Tekin, M. (2000). Hatay Tarihi. AYK Atatürk Kültür Merkezi Başkanlığı, Ankara.

23. UNESCO (1992). Operational Guidelines for The Implementation of The World Heritage Convention. Paris. http://whc.unesco.org/archive/opguide05-annex3-en.pdf, (01.06.2017).

24. UNESCO (2011). Recommendation on the Historic Urban Landscape Adopted by the General Conference at its 36th Session. http://www.historicurbanlandscape.com/themes/196/userfiles/download/2014/3/31/3ptdwdsom3eihfb.pdf, (01.02.2021).

25. Ünlü, T. S. (2017). Kent Kimliğinin Oluşumunda Kentsel Bellek ve Kentsel Mekân İlişkisi: Mersin Örneği. Planlama Dergisi, 27(1); 75-93.

26. Yurdugüzel, O. T., Özçetin, Z. (2015). Tarihi Çevre Koruma Uygulamalarına Eleştirel Bakış: Hamamönü Örneği. 5. Tarihi Eserlerin Güçlendirilmesi ve Geleceğe Güvenle Devredilmesi Sempozyumu Bildiriler Kitabı, 75- 82 . 